\title{
The Necessity of Cooperation between International Organizations
}

\author{
Miguel de Serpa Soares*
}

October 20, 2017

Excellencies,

Ladies and Gentlemen,

It is a pleasure to join you today for the inaugural AII b law lecture. Let us hope this is one of many such events in the years to come.

I congratulate you on this initiative. Being together here today can only be of benefit to us all. I look forward to our discussions.

I wish to speak during my lecture to an issue that is of importance to each and every one of us, individually, as well as to the institutions and organizations that we serve. That is the necessity of cooperation between international organizations.

Let us begin this story like all good stories: in the middle. From there we can see where we have been and speculate as to where we might be going.

We live, I think it is fair to say, in an age of international organization. I have chosen that latter word carefully.

International organization consists not only of international organizations, properly so-called, and here we might specify "intergovernmental organizations" established pursuant to an international agreement, but also organization more broadly. International organization is the organization of international life.

If we were to use the term as it is commonly understood, as opposed to how it might be limited by strict definition — such that it might apply beyond the sphere of cooperation between States - then we could also include within the broad category of international organization other aspects of cooperation between individuals and entities sitting in one place, and other individuals and entities sitting somewhere else, half-way across the world.

* United Nations Under-Secretary-General for Legal Affairs and United Nations Legal Counsel. 
We might think of trade unions or of multinational or transnational corporations; we might think of international courts—not only of the criminal kind, but also those addressing trade and investment disputes. We could think of uniform rules on navigation and telecommunications. We could think of international film festivals or the Olympic games.

We could even think, without trying too hard, of what a former member of the United Nations Office of Legal Affairs, Mr. Oscar Schachter, once referred to as the "invisible college" of international lawyers, "dispersed throughout the world...dedicated to a common intellectual enterprise."

With that context, let us unpack, for a few minutes, what I mean when I say necessity. Later I will speak to what I mean when I refer to cooperation.

Under the heading of necessity, we could ask why such international organization, formal and informal, visible and invisible, exists.

No one person has the answer to that question. And I would not presume to be the world's expert on the subject.

Sitting as we are in the People's Republic of China, we might recall the quote from Confucius that "real knowledge is to know the extent of one's ignorance."

There are things we might know, and there are many more things that we do not. Engaging the unknown and seeking to further our knowledge is difficult, but vital.

Under that guidance, let me say a few words about why we might consider international organization to be necessary.

First, I think it is fair to say that international organization exists because it serves an essential purpose.

The challenges we face and the aims we try to achieve-these cannot be addressed without bringing people together in specific ways.

International organization does that. It takes people from here, and there, with this objective and that objective, with this capacity and that capacity, and puts them in a situation where they can work together to achieve mutual goals. It collects resources-financial, human and material—and coordinates them for the benefit of all.

It is clear that climate change, development, threats to security, among others, do not stop at borders. They traverse them. They are everywhere. They affect us all.

The 2030 Agenda for Sustainable Development and the Sustainable Development Goals and related targets are not for one country, or another; they are for the entire planet and everyone - indeed everything - in it.

As the General Assembly noted at its adoption of the 2030 Agenda, it "is a plan of action for people, planet, prosperity" and "[a]ll countries and all stakeholders, acting in collaborative partnership, will implement" it. 
Clearly this requires some organizational principles, some stitching together of the various threads.

But that is not all. I would like to make a point that goes beyond the usual: international problems, therefore international solutions.

International organization has reached a much more complex level. It is much more calibrated and specialized.

I realize I am addressing a room today that might have forgotten more about economics than I will ever know, but let me borrow from the economic field.

Each specialty, each organization, indeed each actor, that comprises this lively form of international organization of which we are all a part brings a certain comparative advantage.

In order to team these various actors, to maximize the efficiencies that each of them have to achieve the greatest impact, we must recognize the strengths that each brings to the table and look for ways to connect.

The form of international organization differs, necessarily, based what we are trying to connect and for what purpose.

The United Nations, with its broad principles and purposes, enshrined in the Charter, and its three pillars: peace and security, development and human rights-is going to be structured differently, will have different attributes, than an intergovernmental organization with a more specialized mandate.

Its membership might be different; its chief administrative officer and international civilian staff might be empowered to take different kinds of decisions. There are different mandates, and various contexts in which they are implemented.

The United Nations has also been around now for some time. At seventy years young, it has far outlasted its predecessor, the League of Nations.

This comes with certain benefits. The United Nations provides a tremendous platform and, collectively, we can rely on an extensive body of experience and practice.

It also comes with challenges. The Organization must continue to adapt from the vision of 1945 to meet today's demands.

This involves shifts in form and functions, as well as in mandates. The big, punctuating, changes are rare - the United Nations is a large bureaucracy and practices have developed over time; its Member States also have many political aims.

This makes for an active organization but also one that evolves-evolutions, not necessarily revolutions - to address the needs of all of its Member States. It also tends to create a diverse organization, with many pieces, all going in particular directions. 
This can be seen in the recent address by the Secretary-General to the highlevel session of the General Assembly, in which he identified seven threats and tests.

These ranged from the nuclear threat, to terrorism, to unresolved conflicts, to climate change, to inequality, to cybersecurity, to human mobility.

The work of the Organization is far-reaching. These threats and tests are daunting. We cannot address them without working together, and, perhaps more importantly, understanding each other.

They will take all of our skills and all of our attention. As the SecretaryGeneral noted, "we must act as one, because only together, as united nations, can we fulfill the promise of the Charter and advance human dignity for all".

I cannot speak in great detail about the particular objectives of the Asian Infrastructure Investment Bank or, for that matter, of other international financial institutions. But I can appreciate the ambition of what they are trying to achieve, and I can see where synergies between our organizations may exist.

We can all realize the value of mobilizing the financial resources that the world possesses - which are many-and directing them toward the common good, in a way that reduces inequality and enhances opportunity.

Infrastructure is imperative. In a real and practical way, it brings the world together. It improves connectivity, it makes getting from here to there-both literally and figuratively - easier. It creates larger freedom.

By the terms of its Articles of Agreement, the mandate of the Asian Infrastructure Investment Bank includes fostering sustainable economic development and improving infrastructure connectivity in Asia, as well as promoting regional cooperation and partnership in addressing development challenges.

It seeks, in particular, to utilize its resources, to projects and programs that will contribute most effectively to the harmonious economic growth of the region as a whole, with special regard to the needs of less developed members of the region.

It is in this context that we might appreciate the immense potential of the Belt and Road Initiative, which has established close cooperation with a large number of multilateral development banks, including the AIIB.

While the Belt and Road Initiative is different than the 2030 Agenda, both have sustainable development as their overarching objective. Both strive to create opportunities. Both aim to deepen connectivity in infrastructure, trade, finance, policies and, perhaps most important of all, among peoples.

It is crucial to strengthen the links between the Initiative and the Sustainable Development Goals. They can reinforce one another in order to achieve true sustainable development. 
In turn, this highlights the value in connecting the work of the Asian Infrastructure Investment Bank, the majority of whose Membership are along the Belt and Road, and the work of the United Nations.

If we can boil it down, the essence of necessity with respect to cooperation between international organizations is this:

We have mutual aims and different strengths. In order to achieve those mutual aims, we must capitalize on our strengths. An increase in specialization means we must bring more actors into the fold. We must be inclusive, not limited. We must be organized effectively so that we can raise our collective efforts.

Now, I promised that I would explain cooperation, and to its aspects to which I refer in this context.

Let me digress for a moment.

I have been speaking in lofty terms and you might be forgiven for mistaking me for a politician, but let me assure you, I am a lawyer, through and through.

As Legal Counsel for the United Nations, I am charged with creating the structures that enable Organization to function. My tools are memoranda, agreements and opinions. I am measured by the advice I provide and the arrangements I reach on behalf of the Organization.

When they are at their best, international lawyers, those members of the "invisible college," are the architects of the international system.

Handed a vision - for instance, sustainable development-we give it a form.

We develop the principles to bring it to fruition. We sharpen those principles in practice. We ensure those principles can sustain external shocks. We link the work of the United Nations to the work of others so that we may become a stronger force.

The United Nations System that emerged out of the aftermath of World War II is not something esoteric. It is a series of international agreements, beginning with the Charter of the United Nations.

The Charter provides, in its Article 53, that the Security Council shall, where appropriate, utilize such regional arrangements or agencies for enforcement action under its authority. The use of such capacities requires legal arrangements.

Article 57 of the Charter provides that the various specialized agencies, established by intergovernmental agreement and having wide international responsibilities, as defined in their basic instruments, in economic, social, 
cultural, educational, health, and related fields, shall be brought into relationship with the United Nations.

Article 63 of the Charter empowers the Economic and Social Council to enter into such agreements, defining the terms on which the agency concerned shall be brought into relationship with the United Nations. Such agreements are also subject to approval by the General Assembly, consisting of all 193 Member States.

So-called "related" organizations, such as the International Atomic Energy Agency, the World Trade Organization, the Preparatory Commission for the Comprehensive Nuclear-Test-Ban Treaty Organization, the Organization for the Prohibition of Chemical Weapons and the International Organization for Migration, have also been brought into a relationship with the United Nations and comprise a part of the United Nations System.

Each Member organization of the United Nations System has entered into a legal agreement to become so. Each is held to the commitments that it has made.

Those agreements would not have proven as effective and durable as they have been absent the hard work and expertise of international lawyers.

Therefore, when I speak of cooperation in this context, it is not something abstract. It is the nuts and bolts of legal work. It is the process of negotiating and agreeing to cooperative arrangements between and among international organizations.

Such arrangements may take different forms. I noted that the AІІв Charter also requires the Bank to complement, rather than compete with, other development organizations and a number of cooperation agreements have been concluded for such purposes. I can speak only to the practice of the United Nations in this regard, but this may be illustrative of the work in other international organizations as well.

The arrangements that the United Nations reaches with other international organizations occur along a spectrum depending on the extent of the cooperation and the obligations each organization is prepared to undertake.

I mentioned relationship agreements. These might be considered the most formal kind of agreements. The most recent is that which was concluded with the International Organization for Migration in 2016.

This relationship agreement defines the terms on which the United Nations and the International Organization for Migration shall be brought into relationship with each other in order to strengthen their cooperation and enhance their ability to fulfil their respective mandates in the interests of migrants and their Member States. 
It provides, among other things, that the two organizations will "cooperate closely within their respective mandates and to consult on matters of mutual interest and concern."

By the terms of the agreement, the International Organization for Migration will participate in the United Nations System Chief Executives Board for Coordination and its subsidiary bodies.

The agreement also provides for reciprocal representation, as well as measures for information sharing, administrative cooperation and personnel exchanges, among other matters.

The International Organization for Migration is a key contributor in many places where the United Nations deploys operations, including its peacekeeping forces.

Peacekeeping is a central United Nations activity; it is also one of the Organization's most complex and challenging tasks.

In carrying out its peacekeeping functions, the Organization relies on contributions from Member States, as well as other international organizations.

The Secretary-General is seeking, in this context, to forge closer partnerships with key regional organizations such as the African Union, the European Union, the League of Arab States and the Organization of Islamic Cooperation.

He recently concluded a "Joint United Nations-African Union Framework for Enhanced Partnership in Peace and Security," which establishes the following principles, among others:

- Both organizations note the primary role of the Security Council in the maintenance of international peace and security, as well as the essential role of regional arrangements, as also provided for in the Charter;

- Both organizations recognize that the attainment of peace is critical to the achievement of development goals, to which both Organizations are committed;

- In addressing conflict, the organizations will strive, wherever possible, to reach a common understanding of the problems and, through consultative decision-making, develop a collaborative approach and seek to achieve "maximum convergence";

- This will he guided by the principles of mutual respect and, here is that term again, comparative advantage.

The Joint Framework is not a binding agreement; but it does provide clarity in objectives as well as roles and functions. It is hoped that it will serve as a useful guide for continuous cooperation between the two organizations in this most demanding of areas. 
The United Nations continues to strengthen and modernize its peacekeeping forces. This sometimes requires us to work alongside and in partnership with other security actors in the theatre of operations.

In such situations, we must be clear on the legal arrangements. This is important for coordination. It also delineates the responsibility of each organization under international law for its acts and omissions.

The approach of the United Nations is to seek, where possible, to conclude formal arrangements, such as exchanges of letters, with organizations with which it is conducting joint or parallel operations. This is to avoid situations of uncertainty.

Such arrangements have occurred with the European Union forces that operated in Chad, the African Union forces that operate in Somalia-and they may soon occur with respect to the deployment of a $G_{5}$ Sahel Force in Mali, which will operate alongside the United Nations force there.

These arrangements set forth the role and responsibility of each organization and also, importantly, establish that each force will be under separate command and control and operate under its own rules of engagement.

The arrangements also address claims. The standard clause is that each party will handle claims that may be made arising out of acts of its personnel, and that each party would hold the other harmless in respect of such claims.

The parties also renounce the possibility of bringing claims against each other, with the exception of claims concerning loss or damage resulting from the gross negligence or willful misconduct or the other party or its personnel.

Peace and security is of course not the only area where cooperation and clear legal arrangements to that effect are important.

I mentioned earlier the shared goal of the United Nations and the Asian Infrastructure Investment Bank with respect to sustainable development, enshrined in the 2030 Agenda and the AIIB Charter, respectively.

Like many other organizations, including multilateral development banks, the United Nations, represented by the Department of Economic and Social Affairs, recently also entered into a Memorandum of Understanding with the People's Republic of China, to establish a framework of cooperation to promote the implementation of the 2030 Agenda by supporting the Belt and Road Initiative in areas of common interest.

The cooperation envisioned under the Memorandum of Understanding aims to promote and support international cooperation in the pursuit of sustainable development in all countries, including through the Belt and Road Initiative in accordance with the mandates, priorities and comparative advantages of the United Nations and the People's Republic of China. 
I trust that this Memorandum, and the cooperative steps that it envisions, will also contribute to bringing the United Nations and the Asian Infrastructure Investment Bank closer together, noting that most countries along the Belt and Road have joined the Bank and they all have endorsed the 2030 Agenda.

Aside from peace and security and development, there are other technical arrangements between international organizations that also come to mind.

For instance, the United Nations has established a Security Management System that aims to ensure the safety and security of its personnel in various parts of the world.

Various organizations not already a part of the United Nations System, for instance the Asian Development Bank, have entered into a Memorandum of Understanding with the United Nations to participate in the Security Management System.

In all, more than 50 international organizations comprise the membership of the United Nations Security Management System.

These arrangements provide an important basis upon which the safety and security of such personnel can be assured in difficult and insecure environments.

Finally, we might consider more informal arrangements. These could be written or they may evolve through practice.

In the spirit of the "invisible college," my office arranges, each year, for meetings of the legal advisers of the specialized agencies, as well as the separatelyadministered agencies, funds and programmes and the United Nations field legal offices, specifically its peacekeeping and special political missions. Some of you may have participated in such events over the years, including, of course, Mr Gerard Sanders, who had served as General Counsel at IFAD, a UN specialized agency, before he joined the АІІв.

At these meetings, we do not necessarily discuss formal legal arrangements. Rather, we share experiences and consider issues of mutual concern.

There is something special that emerges when we are able to sit together in an informal setting. Lawyers share a specialized language. We are able to communicate and understand each other. I expect that that spirit is also captured here today.

Excellencies,

Ladies and Gentlemen,

I hope that you have found these remarks illustrative of the necessity of cooperation between international organizations. 
This is a matter that will continue to demand our attention and our hard work as lawyers and as international civil servants.

If you will allow me, let us return, in conclusion, to Confucius once again. You will forgive me. But I find his comments and quotations to be very insightful.

The quotation that I will turn to now is the following:

The man who moves a mountain begins by carrying away small stones.

When I read this quotation, I think of the mountains, the challenges that we all have. There are those that we might face alone; but, as I have tried to demonstrate, there are many more that we face together.

When we consider our mountains, there are some that require an ascent, while others might be tunneled. Still others might be brought low with force.

In order to be effective, we might face each challenge not by thinking of its totality, of its sheer size, but of the series of measures, day in and day out, that might allow us to begin, step by step, stone by stone, to move it.

If we commit to such a process; if we commit to working together-then we might find, over the course of time, that we have made that mountain a little less impassable.

Such is my hope; and I trust it is yours as well. Thank you. 